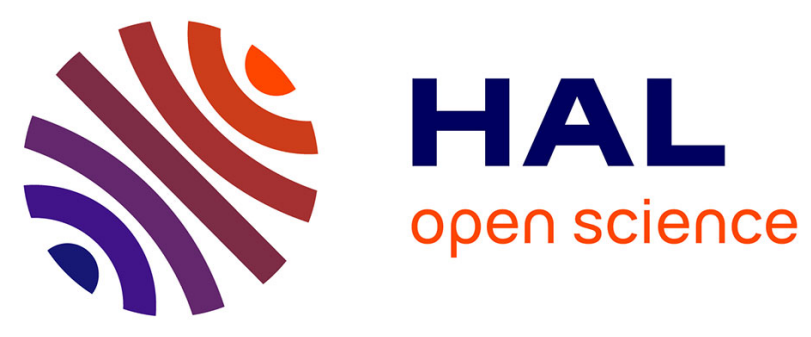

\title{
Effects of redox oscillations on the phosphogypsum waste in an estuarine salt-marsh system
}

Evgenia-Maria Papaslioti, Rafael Pérez-López, Annika Parviainen, van T.H.

Phan, Claudio Marchesi, Alejandro Fernandez-Martinez, Carlos Garrido, José

Nieto, Laurent Charlet

\section{To cite this version:}

Evgenia-Maria Papaslioti, Rafael Pérez-López, Annika Parviainen, van T.H. Phan, Claudio Marchesi, et al.. Effects of redox oscillations on the phosphogypsum waste in an estuarine salt-marsh system. Chemosphere, 2020, 242, pp.125174. 10.1016/j.chemosphere.2019.125174 . hal-03043993

\section{HAL Id: hal-03043993 https://hal.science/hal-03043993}

Submitted on 5 Jan 2021

HAL is a multi-disciplinary open access archive for the deposit and dissemination of scientific research documents, whether they are published or not. The documents may come from teaching and research institutions in France or abroad, or from public or private research centers.
L'archive ouverte pluridisciplinaire HAL, est destinée au dépôt et à la diffusion de documents scientifiques de niveau recherche, publiés ou non, émanant des établissements d'enseignement et de recherche français ou étrangers, des laboratoires publics ou privés. 


\section{Effects of redox oscillations on the phosphogypsum waste in an estuarine salt-marsh system}

Evgenia-Maria Papaslioti ${ }^{\text {a, b* }}$, Rafael Pérez-López ${ }^{\text {, }}$, Annika Parviainen ${ }^{a}$, Van T.H. Phan $^{\text {c }}$, Claudio Marchesi ${ }^{d}$, Alejandro Fernandez-Martinez ${ }^{e}$, Carlos J. Garrido ${ }^{a}$, José M. Nieto ${ }^{\mathrm{b}}$, Laurent Charlet ${ }^{\mathrm{e}}$

${ }^{a}$ Instituto Andaluz de Ciencias de la Tierra, CSIC \& UGR, Avenida de las Palmeras 4, 18100 Armilla (Granada), Spain

${ }^{\mathrm{b}}$ Department of Earth Sciences \& Research Center on Natural Resources, Health and the Environment, University of Huelva, Campus ‘El Carmen’, E-21071 Huelva, Spain

${ }^{\mathrm{c}}$ Institut de Planétologie et d'Astrophysique de Grenoble, CNRS, Université Grenoble Alpes, F-38000 Grenoble, France

${ }^{d}$ Department of Mineralogy and Petrology, UGR, Avda. Fuentenueva s/n, E-18002 Granada, Spain

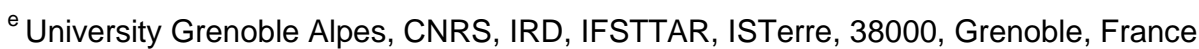




\section{Abstract}

Salt marshes are natural deposits of heavy metals in estuarine systems, where sulphide precipitation associated with redox changes often results in a natural attenuation of contamination. In the present study, we focus on the effects of variable redox conditions imposed to a highly-polluted phosphogypsum stack that is directly piled over the salt marsh soil in the Tinto River estuary (Huelva, Spain). The behaviour of contaminants is evaluated in the phosphogypsum waste and in the marsh basement, separately, in controlled, experimentally-induced oscillating redox conditions. The results revealed that $\mathrm{Fe}$, and to a lesser extent $\mathrm{S}$, control most precipitation/dissolution processes. Ferric iron precipitates in the form of phosphates and oxyhydroxides, while metal sulphide precipitation is insignificant and appears to be prevented by the abundant formation of Fe phosphates. An antagonistic evolution with changing redox conditions was observed for the remaining contaminants such as $\mathrm{Zn}, \mathrm{As}$, Cd and $\mathrm{U}$, which remained mobile in solution during most of experimental run. Therefore, these findings revealed that high concentrations of phosphates inhibit the typical processes of immobilization of pollutants in salt-marshes which highlights the elevated contaminant potential of phosphogypsum wastes on coastal environments.

Keywords: Phosphogypsum; estuarine salt-marshes; redox oscillations; Fephosphates; trace elements mobility. 


\section{Introduction}

Significant pollution sources including metal mining, industrial activity and waste disposal have led to extensive contamination of environmental systems, such as marsh soils (e.g., Vega et al., 2008; 2009). Such systems can act as important sinks for great loads of contaminants, both organic and inorganic, that are transferred through the estuarine water and the suspended sediments affected by tidal variations (Andrade et al., 2002; 2004; Vega et al., 2008).

The biogeochemical cycling and the behaviour of elements in such ecosystems depend, among others, on redox reactions. Redox processes play a key role in many environmental systems as they control the mobility, the chemical speciation and the toxicity of major and trace redox sensitive elements (e.g., Fe, Mn, C, P, N, S, Cr, As and U), as well as the formation and/or dissolution of solid phases (Borch et al., 2009; Frohne et al., 2011); i.e., the precipitation of sulphides is a driving process, conventionally met in estuarine marsh soil systems (Castillo et al., 2012; Pérez-López et al., 2018). Redox processes are usually kinetically controlled, and often mediated by microorganisms, so that oxic-anoxic oscillations of redox conditions have to be understood, as they are frequent in estuarine salt-marsh systems due to daily tides and subsequent changes of water table levels (Ann et al., 2000; Du Laing et al., 2009). According to Nernst equation, oxidation produces protons and thus, a drop in $\mathrm{pH}$ value, while the opposite happens during reduction (Yu et al., 2007), which means that $\mathrm{pH}$ and Eh may have, if not buffered, reversed behaviour during redox processes. Hence, the frequent Eh changes that occur in salt marsh soils due to oscillation of the water table, lead to subsequent $\mathrm{pH}$ alterations (Frohne et al., 2011), which is also a key factor for elemental mobility. 
Contaminants could be also released from the redox-dynamic marsh soil systems depending on the hydraulic regime (Ann et al., 2000). During dry periods, the near surface top soil is subjected to oxic conditions, while if flooded, i.e., under water saturation, anaerobic conditions prevail as oxygen diffusion from the atmosphere, a slow phenomenon, does not balance $\mathrm{O}_{2}$ consumption during organic material mineralisation by aerobic bacteria. Hence, microbial processes affect the mobility and speciation of redox-sensitive elements and the solubility/dissolution of mineral phases (Watts et al., 2013; Couture et al., 2015). Some non-redox sensitive elements (e.g., $\mathrm{Cu}^{2+}$ and $\mathrm{Co}^{2+}$ in natural environments) could be also impacted indirectly by redox processes, e.g., by natural organic matter mineralisation and $\mathrm{Fe}$ and Mn (hydr)oxide mineral phases reductive dissolution (Borch et al., 2010). With respect to the importance of studying redox processes, especially in anthropogenic contaminated environmental systems, it is required to understand whether natural attenuation occurs in these systems, or in the contrary whether other remediation strategies, e.g., based on microbial degradation or reductive sequestrations, must be implemented (Wu et al., 2006; Polizzotto et al., 2008).

Phosphogypsum wastes are generated by the phosphate fertiliser industry, during the production of phosphoric acid via the reaction of sulphuric acid with a phosphate ore (i.e., apatite). It is estimated that the total amount of phosphogypsum produced worldwide until 2006 was about 6 billion tones (IAEA, 2013; Cánovas et al., 2018), while the expected annual amount in the future is around 100-280 Mt (Yang et al., 2009; Macías et al., 2017). This industry is usually located on coastal areas, whereas the waste is transported and deposited nearby, e.g., on redoxdynamic estuarine salt-marsh systems. Redox fluctuations affect the stability or leaching of phosphogypsum-related contaminants by controlling the oxidation states 
of many compounds (e.g., sulphur, iron and uranium) associated with these wastes and thus, their mobility (Papanicolaou et al., 2010). Large phosphogypsum disposal stacks could exhibit different redox gradients with depth as the upper unsaturated zones are likely to be subjected to oxidizing conditions, particularly in stacks supported directly on organic matter-rich marsh soils (Lottermoser, 2007; PérezLópez et al., 2011).

\section{Environmental setting and objectives}

One singular case of redox-dynamic system is the phosphogypsum disposal area located in Huelva, SW Spain, that is directly stack-piled over the salt marshes of the Tinto River estuary without any impermeable barrier (Fig. 1). The marshes belong to one of the most important marsh ecosystems in Europe (Borrego et al., 2013), declared UNESCO Biosphere Reserve and RAMSAR-NATURA wetland with high-priority protection status. The industrial production of phosphoric acid in Huelva mainly used sedimentary phosphate rock ore imported from Morocco. Between 1968 and 2010, this activity led to the disposal of approx. 100 Mt of phosphogypsum wastes in stacks covering an area of $12 \mathrm{~km}^{2}$ on the salt marshes. The stacks are located within the tidal prism of the Huelva Estuary, which has a great influence on the weathering of phosphogypsum waste by means of estuarine tidal waters (Papaslioti et al., 2018). The highly-contaminated groundwater contained in the phosphogypsum piles migrates towards the edge of the stack forming acidic leakages, known as edge outflows, that have polluted the estuary until nowadays (Pérez-López et al., 2016; Papaslioti et al., 2018). Another source of contamination is the process water present on the surface of the piles, used to slurry the phosphogypsum and transport it from the industry. 
The direct contact of the phosphogypsum stack with the organic matter-rich marsh soil basement leads to its weathering in deep zones under reducing conditions with stagnant and non-renewable waters. Anaerobic conditions are imposed by organic matter decomposition associated with microbial activity of sulphate-reducing bacteria (SRB), resulting in aqueous reduction of sulphate from phosphogypsum to sulphide. This process may lead to metal mobility restriction due to precipitation of metal sulphides (Pérez-López et al., 2011; 2018). However, partial oxidation of these sulphides in the marsh contact also occurs due to the hydrological connection between the stack and the estuary by saline intrusion (Pérez-López et al., 2018). Therefore, phosphogypsum can be subjected to weathering under reduction-oxidation cycles likely controlled by tidal variations.

Currently, the disposal area is divided into four zones (Fig. 1). Zones 2 and 3 are directly exposed to weathering, whereas zones 1 and 4 have been the subject of rehabilitation, e.g., the implementation of a top soil cover. This cover includes a vegetation layer rich in organic matter that also may act as carbon source, and thus may enhance the activity of naturally-occurring SRB in the phosphogypsum (Castillo et al., 2012). Even small amounts of organic material could be enough to lead to dissolved oxygen depletion and thus, to the establishment of anaerobic conditions (Pérez-López et al., 2011). Thus, the Huelva phosphogypsum is additionally affected by redox processes because of the complex soil cover applied to rehabilitate the industrial site. However, previous studies (Pérez-López et al., 2016; Papaslioti et al., 2018) have shown that the rehabilitation measures are ineffective and the edge outflows still leak to the estuary, highlighting the importance in improving the current remediation techniques. 


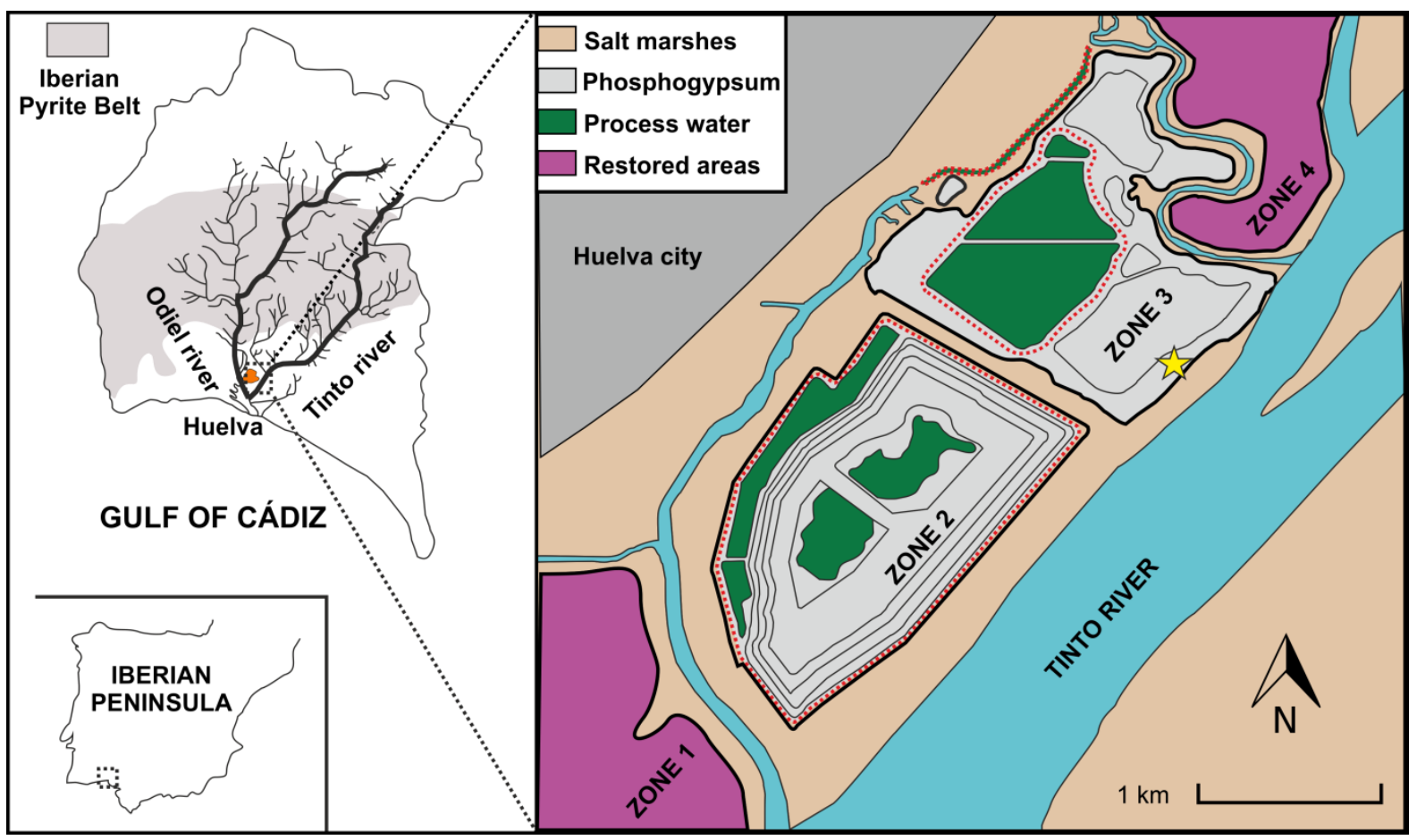

Figure 1: Study area description showing the phosphogypsum stack disposed on the salt marsh soil. The star indicates the sampling point.

The full awareness of the redox processes occurring in a redox-dynamic phosphogypsum stack is the aim of the current study. It should provide important insights for an effective remediation to promote the contaminants attenuation to the environment. Therefore, this study evaluates the contaminant driving geochemical processes (i) in the phosphogypsum piles, and (ii) in its marsh soil basement, both present in an estuarine salt-marsh system, mimicked by experimentally induced redox oscillations, under controlled conditions.

\section{Materials and methods}

\subsection{Preparation of suspensions}

For the redox oscillation experiments, two solid samples were collected from the stack surface in zone 3 using a soil-sampling auger (Fig. 1): (i) phosphogypsum at $5 \mathrm{~m}$ depth, where metals availability in the pore water is high (Pérez-López et al., 
2018), and (ii) underlying salt marsh soil located at $8 \mathrm{~m}$ depth. Samples were preserved in heat sealed Mylar ${ }^{\circledR}$ bags under $\mathrm{N}_{2}$ atmosphere until the experiments. This soil with high organic matter content could serve as a source of organic $C$ and of bacteria.

Two soil suspensions of $1 \mathrm{~L}(<1 \mathrm{~mm}$ fraction, $100 \mathrm{~g}$ dry soil/L) were prepared for the experiments, one with phosphogypsum and another one with salt marsh soil. The suspensions were prepared by equilibrating in anoxic conditions each soil sample with synthetic degassed pore water for 1 week prior to the experiments. Each synthetic water was prepared by mimicking the solution composition of the phosphogypsum and the salt marsh soil in depth. For that purpose, Milli-Q water was enriched with an aliquot of salts (iron chloride, sodium arsenate, cadmium chloride, zinc sulphate, disodium hydrogen phosphate, calcium chloride, sodium chloride, sodium sulphate) and $\mathrm{U}_{2} \mathrm{O}_{5}$ Inductively Coupled Plasma-Mass Spectrometry standard solution, in order to simulate the natural waters (pore water) occurring within the soil samples (Table 1).

\subsection{Experimental set-up and sample treatment}

The experiment was performed using a custom two part Pyrex® glass redox stat bioreactor system designed by Thompson et al. (2006) and modified later by Parsons et al. (2013); the system was also used in similar, recent studies (Markelova et al., 2018; Phan et al., 2018; 2019) (Fig. 2). The lower part of the reactor (AceGlass Inc, NJ, USA) contained a working volume of $1 \mathrm{~L}$ including the use of a water jacket to allow precise temperature control. Ethylene glycol was added to the temperature regulating circuit to avoid fungal and bacterial growth. The upper part of the reactor contained a headspace volume of approximately $300 \mathrm{~mL}$ and used aceglass threaded connections for sampling, electrodes and mechanical agitation (seals 
secure up to 2.4 bar of internal/external pressure difference) that were Teflon coated in order to avoid any metal contamination. All parts of the equipment were washed with $5 \% \mathrm{HNO}_{3}$ and rinsed thoroughly in ultra-pure water prior to the experiment onset. Two water baths were connected to the system; one to maintain the temperature at $25 \pm 1{ }^{\circ} \mathrm{C}$ inside the reactors and another at $5{ }^{\circ} \mathrm{C}$ to keep cool the distillations columns.

The suspensions were inserted in the reactors and were subjected to six cycles of 7 days each, by alternating oxic and anoxic conditions. To impose redox potential (Eh) change, the sparging gas was modulated between $\mathrm{N}_{2}: \mathrm{CO}_{2}$ (392 ppmv) during the anoxic cycle and compressed air $\mathrm{O}_{2}: \mathrm{N}_{2}: \mathrm{CO}_{2}$ under constant $\mathrm{pCO}_{2}\left(10^{-3.5} \mathrm{~atm}\right)$ during oxic weeks. Gas flow rate $(30 \mathrm{~mL} / \mathrm{min})$, gas atmospheric temperature $(25 \pm 1$ $\left.{ }^{\circ} \mathrm{C}\right)$ were controlled by an Agilent switching unit, a relay board and a system of solenoid valves. Samples were collected daily and then were centrifuged, filtered $(0.45 \mu \mathrm{m})$ and stored in the fridge until analysis. Samples from anoxic weeks were taken daily, and treated and stored inside a $\mathrm{N}_{2}$-filled anaerobic chamber $\left(\mathrm{O}_{2(\mathrm{~g})}<1\right.$ $\mu \mathrm{L} / \mathrm{L})$ to avoid oxidation. Reactors were covered with an aluminium foil during the experiments to prevent the formation of hydrogen peroxide and the photodegradation of the contaminants. During the experiment, the bacteria present in the suspension are expected to consume the existing organic matter. Thus, $8.33 \mathrm{mmol} / \mathrm{L}$ of cellobiose $\left(\mathrm{C}_{12} \mathrm{H}_{22} \mathrm{O}_{11}\right.$ - Sigma-Aldrich) was added in the suspensions at the start of every reducing cycle in order to replace the labile organic matter that is needed to stimulate the bacteria in the bioreactors (Phan et al., 2018). 


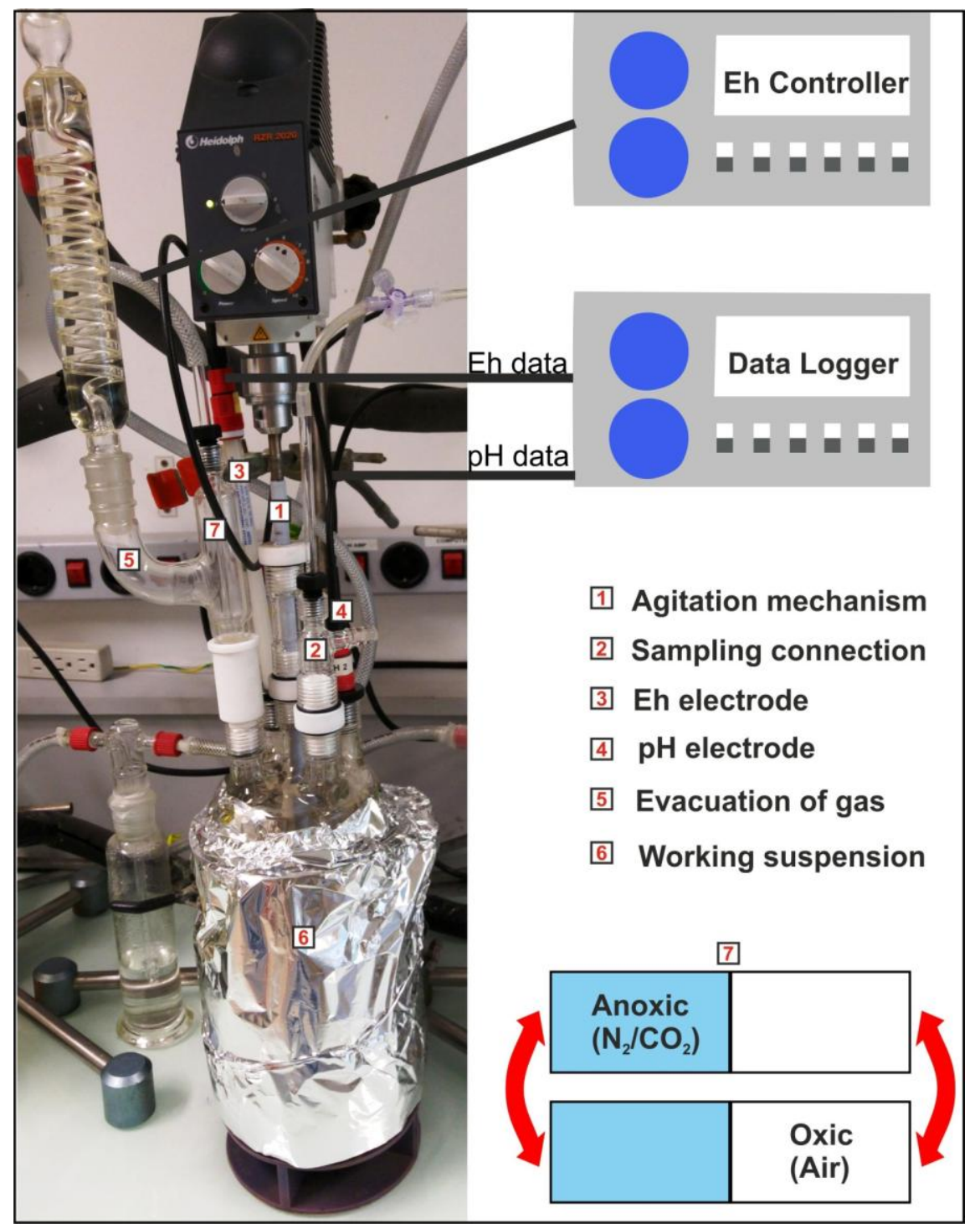

Figure 2: Arrangement of the bioreactor used for the redox experiments.

\subsection{Eh-pH measurements}

Continuous monitoring (every $30 \mathrm{~min}$ ) of the Eh and $\mathrm{pH}$ was conducted during the 6-week experiments using electrodes inserted in the suspensions (Fig. 2). Solid polymer open junction $\mathrm{pH}$ and Eh electrodes (Mettler-Toledo Xerolyt, France) were placed inside the reactors through the corresponding connections. The electrode signals were connected to field-effect transistor (FET) instrumentation amplifiers with high input impedance. The signal was then passed to an Agilent acquisition/switching unit (34970a) connected to a PC running Agilent BenchLink 
Data Logger 3 software. The measured Eh values were corrected for the reference electrode's standard voltage $\left(+207 \mathrm{mV}\right.$ at $\left.25^{\circ} \mathrm{C}\right)$ relative to the standard hydrogen electrode (SHE) and referred to $\mathrm{Ag} / \mathrm{AgCl}(3 \mathrm{M} \mathrm{KCl})$ reference electrode.

A three-point calibration ( $\mathrm{pH} \mathrm{4,7}$ and 10) was performed for the $\mathrm{pH}$ electrodes at the start and the end of the experiments showing that electrode response had not shifted importantly. Real values were calculated based on the calibration of the electrodes performed prior to the experiments.

\subsection{Analytical methods}

\subsubsection{Aqueous elemental analysis}

Major element $(\mathrm{Ca}, \mathrm{K}, \mathrm{Mg}$ and $\mathrm{Na})$ concentrations and those of anions $\left(\mathrm{F}^{-}, \mathrm{Cl}^{-}\right.$, $\mathrm{Br}, \mathrm{SO}_{4}{ }^{2-}, \mathrm{PO}_{4}{ }^{3-}$ ) and ammonia were measured by Inductively Coupled PlasmaAtomic Emission Spectroscopy (ICP-AES) by a Jobin Yvon Ultima 2 instrument and by a high-performance liquid chromatography system (HPLC) using a Metrohm 883 basic ion chromatograph (IC) equipped with Metrosep columns, respectively. Aluminum, $\mathrm{Fe}, \mathrm{Mn}$ and trace elements ( $\mathrm{Cr}, \mathrm{Co}, \mathrm{Ni}, \mathrm{Cu}, \mathrm{Zn}, \mathrm{As}, \mathrm{Cd}, \mathrm{Sb}, \mathrm{Pb}$, and $\mathrm{U}$ ) were determined by Inductively Coupled Plasma-Mass Spectrometry (ICP-MS) by an Agilent 8800 Triple quadrupole device. Detection limits were: $0.2 \mathrm{mg} / \mathrm{L}$ for $\mathrm{S}, 0.1$ $\mathrm{mg} / \mathrm{L}$ for $\mathrm{Na}, 0.05 \mathrm{mg} / \mathrm{L}$ for $\mathrm{K}$ and $\mathrm{Mg}, 0.02 \mathrm{mg} / \mathrm{L}$ for $\mathrm{Ca}$ and $\mathrm{P}, 2 \mu \mathrm{g} / \mathrm{L}$ for Al, $0.5 \mu \mathrm{g} / \mathrm{L}$ for Fe, $0.04 \mu \mathrm{g} / \mathrm{L}$ for $\mathrm{Mn}$ and $0.02 \mu \mathrm{g} / \mathrm{L}$ for trace elements. Certified Reference Materials SLRS-5 (river water) supplied by the National Research Council of Canada (CNRC) and 1640A (natural water) by the National Institute of Standards and Technology (NIST), were analysed by ICP-MS as external standards every four samples. Blank solutions with the same acid matrix as the samples were also analysed. The average measurement error was below $5 \%$ for all the analyses. 
Determination of inorganic arsenite $\left(\mathrm{As}^{3+}\right)$ and arsenate $\left(\mathrm{As}^{5+}\right)$ was conducted using coupling liquid chromatography LC (Thermo Scientific, SpectraSystem P4000) with ICP-MS with the internal standard Ge (Thermo Scientific, XSeries 2) according to the method described by Bohari et al. (2001). The detection limit was $0.09 \mu \mathrm{g} / \mathrm{L}$ for $\mathrm{As}^{3+}$ and $0.41 \mu \mathrm{g} / \mathrm{L}$ for $\mathrm{As}^{5+}$, with a precision better than $5 \%$.

The "methylene blue method" (Cline, 1969) was applied for the total S(-II) analysis in solution, in which standard stock $\mathrm{Na}_{2} \mathrm{~S}$ was used for the preparation of the standard solutions in order to build the calibration curve and to treat the results. For $\mathrm{Fe}^{2+}$ measurement, the ferrozine assay was used, modified according to Viollier et al. (2000). To obtain mobilised $\mathrm{Fe}^{2+}$ concentration in solution, an aliquot of sample was added to ferrozine solution. Standard stock solution was prepared using $\mathrm{FeCl}_{2}{ }^{*} 4 \mathrm{H}_{2} \mathrm{O}$ and standards of different concentrations were prepared via serial dilutions using $\mathrm{HCl}$ in order to mobilise $\mathrm{Fe}^{2+}$. Samples and standards were measured immediately after preparation via UV-Vis spectroscopy (Lamda 35, Perkin Elmer) at $664 \mathrm{~nm}$ and $562 \mathrm{~nm}$ absorbance for sulphide and iron, respectively.

\subsubsection{Dissolved Organic Carbon}

Dissolved Organic Carbon (DOC) measurement of the filtered supernatants was conducted by Shimadzu VCSN analyser (TOC-5000A, Shimadzu, France) via the direct NPOC (Non-purgeable Organic Carbon) method by pre-acidifying and prepurging the sample to remove the Total Inorganic Carbon (TIC) and Purgeable Organic Carbon (POC), respectively. POC was partly removed from the sample by gas stripping, while the sample was acidified within $\mathrm{pH} 2$ and 3 by adding a small portion of $\mathrm{HCl}$ and then TIC was removed from the acidified sample by purging with a purified gas. Thus, DOC was determined directly by means of Total Carbon (TC) 
measuring method as TC equal Total Organic Carbon. The detection limit was 0.3 $\mathrm{mg} / \mathrm{L}$ and the precision was better than $2.5 \%$.

\subsubsection{Adenosine tri-phosphate}

The adenosine tri-phosphate (ATP) test is a way to rapidly measure growing microorganisms through detection of ATP, a molecule found in and around active living cells. The ATP concentrations were determined by measuring luminescence levels in relative light units (RLU) using the BacTiter-Glo Microbial Cell Viability Assay Kit (G8233; Promega Corporation, Dübendorf, Switzerland), following an optimized procedure (Hammes at al., 2010). The detection limit of the luminescencebased ATP procedure is $0.0001 \mathrm{nM}$ with a standard deviation of $<5 \%$. Measurements were performed by a Lumar LB 9507 luminometer (Berthold Technologies, Bad Wildbad, Germany). The ATP reagent -prepared by mixing the BacTiter-Glo ${ }^{\mathrm{TM}}$ Buffer with the BacTiter-Glo ${ }^{\mathrm{TM}}$ Substrate- was mixed with the slurry samples in a ratio of $1: 1$. The intensity measured (of each mixture) was correlated to ATP concentration using an ATP standard (BioThema Luminescent Assays, 45-051 ATP Standard $10 \mu \mathrm{M} 5 \mathrm{~mL}$, Sweden) for calibration.

\subsection{Geochemical modelling}

Geochemical calculations were performed for all the solutions, which were collected during the redox oscillations experiments, by the PHREEQC-2 code (Parkhurst and Appelo, 2005) using the Minteq.v4 database (Allison et al., 1991), allowing evaluation of the contaminants behaviour, along with the geochemical processes occurring during redox oscillations. The model was used to determine saturation indices $(\mathrm{SI})$ with respect to relevant mineral phases that may play a key role in the mobility of the dissolved species under redox alterations. Negative SI indicates that the solutions are undersaturated with respect to the target minerals 
and, therefore, their dissolution is thermodynamically favored over precipitation. On the contrary, positive $\mathrm{SI}$ indicates that mineral precipitation is favored. Finally, SI close to zero indicates that solutions are close to equilibrium with respect to a given mineral phase and neither dissolution nor precipitation is thermodynamically predicted. The main reactions and their equilibrium constants are given in Table 3.

\subsection{Solid phase analysis}

Solid phase analysis was performed on the dried slurry collected during the redox experiments. The solid phases were analysed by a Field-Emission Scanning Electron Microscope with an AURIGA system (FESEM; ZEIS SMT) and a Scanning Electron Microscope of Variable Pressure (VPSEM; ZEIS SUPRA ${ }^{\mathrm{TM}}$ 40VP), both equipped with backscattered and secondary electron detectors coupled with Energy Dispersive X-ray Spectrometer (EDS).

\section{Results}

\subsection{Eh and $\mathrm{pH}$}

The redox potential of the suspensions subjected to redox oscillations was relatively high, with Eh values systematically higher in the marsh soil (from 265 to $772 \mathrm{mV}$ ) than in the phosphogypsum experiment (from 170 to $560 \mathrm{mV}$ ) (Table 2; Fig.3). Both suspensions followed similar trend, with an Eh decreasing in the $2^{\text {nd }}$ and $3^{\text {rd }}$ anoxic periods and increasing in the oxic ones (Fig. 3A and B). In principle, a negative correlation would be expected from Nerst equation between $\mathrm{pH}$ and Eh, but this was not observed in our experiments. Instead, both systems managed to have a well-buffered $\mathrm{pH}$, with more acidic conditions observed in the marsh soil system (from 3.16 to 3.51 ) than in the phosphogypsum system (from 4.59 to 4.69 ) (Table 2; Fig. 3A and B). 
A weak positive correlation between $\mathrm{Eh}$ and $\mathrm{pH}$ was described in similar studies on other redox sensitive systems (Antić-Mladenović et al., 2010; Frohne et al., 2014). The dynamics of $\mathrm{pH}$ often reflect the presence of microorganisms and organic matter (Husson, 2013; Wang et al., 2013), the oxidation of pyrite (Phan et al., 2018) or the hydrolysis of Fe (Karimian et al., 2018), all generating acidity to the system, they may lead to the continuously low $\mathrm{pH}$ conditions during the present experiments. 


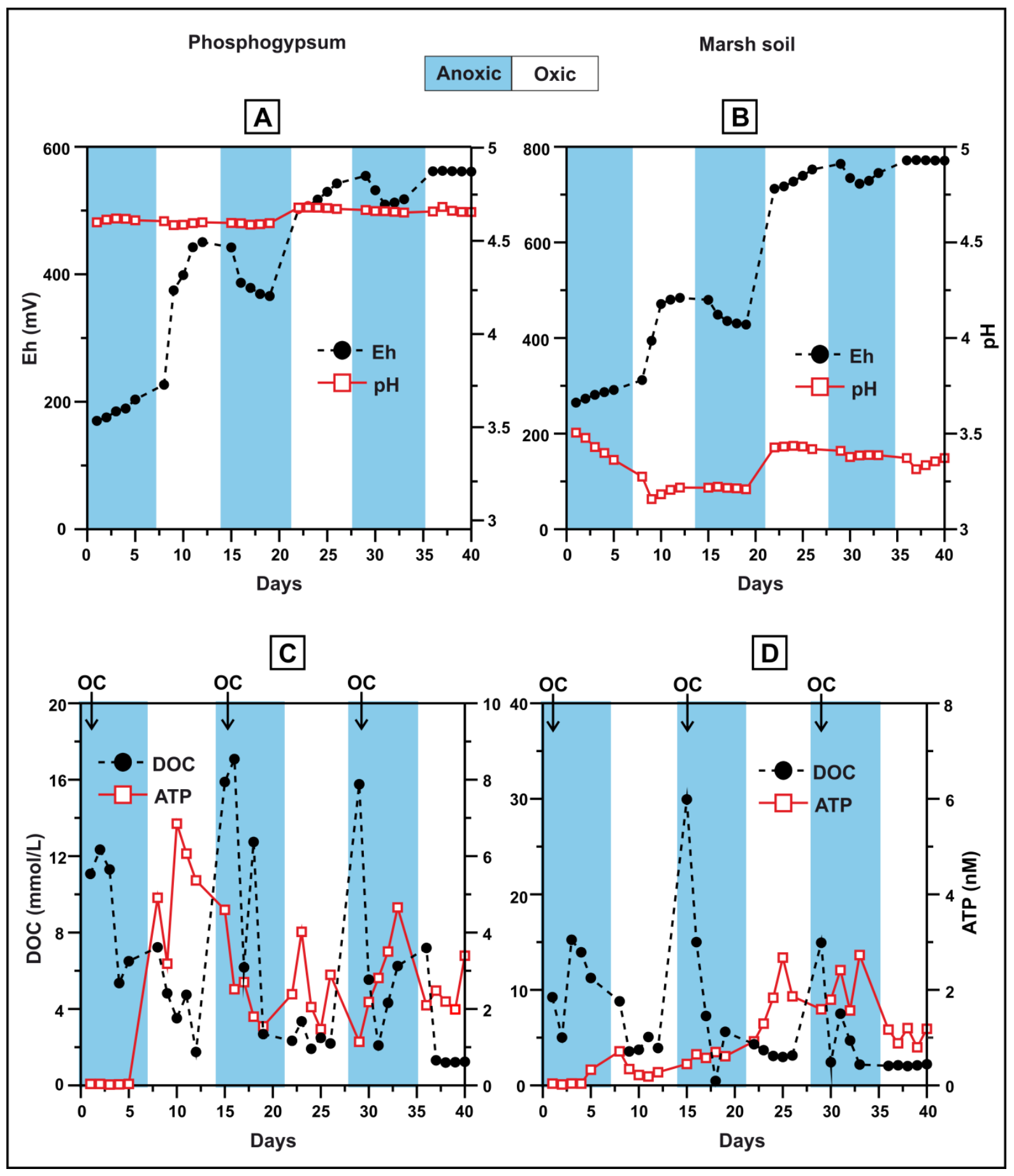

Figure 3: Eh-pH parameters ( $\mathbf{A}$ and $\mathbf{B}$ ), microbial activity and organic matter (C and $\mathbf{D}$ ) in the phosphogypsum and marsh soil systems, respectively. The $\mathrm{OC}$ arrow indicates the addition of cellobiose at the beginning of the anoxic cycles.

\subsection{DOC consumption and ATP levels as tracers of the microbial activity}

Both suspensions subjected to redox oscillations followed similar trend with respect to DOC. Phosphogypsum samples presented slightly lower values (from 
1.20 to $17.1 \mathrm{mmol} / \mathrm{L}$ ) than those corresponding to the marsh soil (from 0.47 to 29.9 $\mathrm{mmol} / \mathrm{L}$ ) (Table 2). After the addition of the cellobiose at the onset of every anoxic cycle, the DOC amount decreased constantly until reaching the lowest levels at the subsequent oxidising half cycles (Fig. 3D), as it was consumed by bacteria faster than it is replenished by hydrolysis (Parsons et al., 2013), and/or due to respiration and oxidation of $\mathrm{Fe}^{2+}, \mathrm{S}$ and As (Phan et al., 2018), with DOC consumption usually linked to their kinetics. The correlations between DOC with Eh and $\mathrm{pH}$ were not significant, a case also described by Frohne et al. (2011).

At the first half of the phosphogypsum experiment, ATP concentration was minimal during the anoxic conditions and higher during the oxic cycles indicating the presence of aerobic bacteria (Fig. 3C). On the other hand, the microbial inactiveness in the marsh soil suspension was highlighted during the same period at both conditions (Fig. 3C). This behaviour was expected due to the strong anoxic environment that exists naturally in the marsh soil because of the high content in decomposing organic matter, which probably does not favour the aerobic bacteria growth. Nevertheless, microbial activity slightly increased at the second half of the marsh soil experiment consistent with the higher Eh conditions. Higher ATP values were observed during anoxic conditions in both systems at that period, indicating that the rates of the microbially mediated solubilisation of POM (Particulate Organic Matter) exceeded the rates of DOC consumption by heterotrophic metabolism, as also observed in Parson et al. (2013) and Phan et al. (2018). On the contrary, this microbial activity increase cannot be supported by the development of SRB due to the low $\mathrm{pH}$ conditions and the limited sulphate reduction and thus, to the low sulphide concentrations in both our systems, corroborating the fact that anaerobic 
conditions could not be effectively reached, as shown by the constantly elevated Eh values (Fig. 3A and B).

\subsection{Sulphur release and iron cycling}

The total amount of $S$ in solution presented no correlation with the Eh in both systems. No significant differences between oxic and anoxic conditions were found in our study. Despite following similar pattern, $S$ concentrations presented higher values in the phosphogypsum compared to the marsh soil (Table 2; Fig. 4A and B). Aqueous $\mathrm{HS}^{-}$concentration did not present important or consistent variations, and was constantly present at low concentrations in both systems, presenting only occasional decrease under anoxic conditions (e.g. $31^{\text {st }}$ day in the phosphogypsum experiment), (Fig. 4A and B), indicating limited sulphate reduction during the anoxic half-cycles. Nevertheless, supersaturation with respect to some sulphide phases was predicted by PHREEQC calculations, e.g. chalcopyrite and pyrite (Table 3), that can be related with occasional sulphide precipitation.

In phosphogypsum both total $\mathrm{Fe}$ and $\mathrm{Fe}^{2+}$ decreased dramatically soon after the first days of the experiment, already on the $3^{\text {rd }}$ day (from 338 to $2.14 \mu \mathrm{mol} / \mathrm{L}$ ) (Table 2). The low $\mathrm{Fe}^{2+}$ values were preserved in each oxic phase, the higher $\mathrm{pH}$ (4.5) favouring slightly $\mathrm{Fe}^{2+}$ oxidation by $\mathrm{O}_{2}$. Ferrous iron increased during the anoxic half cycles, while it was almost depleted from solution at the oxic ones, as it was likely oxidised to $\mathrm{Fe}^{3+}$ and precipitated as newly-formed phase explicating the decrease in total Fe (Fig. 4C). On the contrary, in marsh soil, Fe ${ }^{2+}$ was very close to the total Fe, even in oxic periods, and the first drop was observed at the onset of the first oxic phase ( $9^{\text {th }}$ day from 408 to $90.8 \mu \mathrm{mol} / \mathrm{L}$ ), probably due to the limited oxidation by $\mathrm{O}_{2}$ (Fig. 4D). 
The depletion of Fe from the solution was consistent with the solid phases that precipitated according to PHREEQC calculations; $\mathrm{Fe}^{3+}$ produced by $\mathrm{Fe}^{2+}$ oxidation was predicted to precipitate as oxyhydroxide phases; i.e., goethite and lepidocrocite (Table 3). This was mainly evident in the phosphogypsum and less in the marsh soil, where the calculated SI corresponded either to undersaturation or close to saturation with respect to the Fe phases, a case consistent with the poor oxidation of Fe during the oxic cycles. Moreover, supersaturation in $\mathrm{Fe}^{3+}$ phosphates was noted in the form of strengite at both experiments (Table 3), while Fe phosphate precipitation would explain the decrease of the iron amount in solution in the marsh soil experiment during the oxic cycles, despite there is no strong oxidation of Fe. 


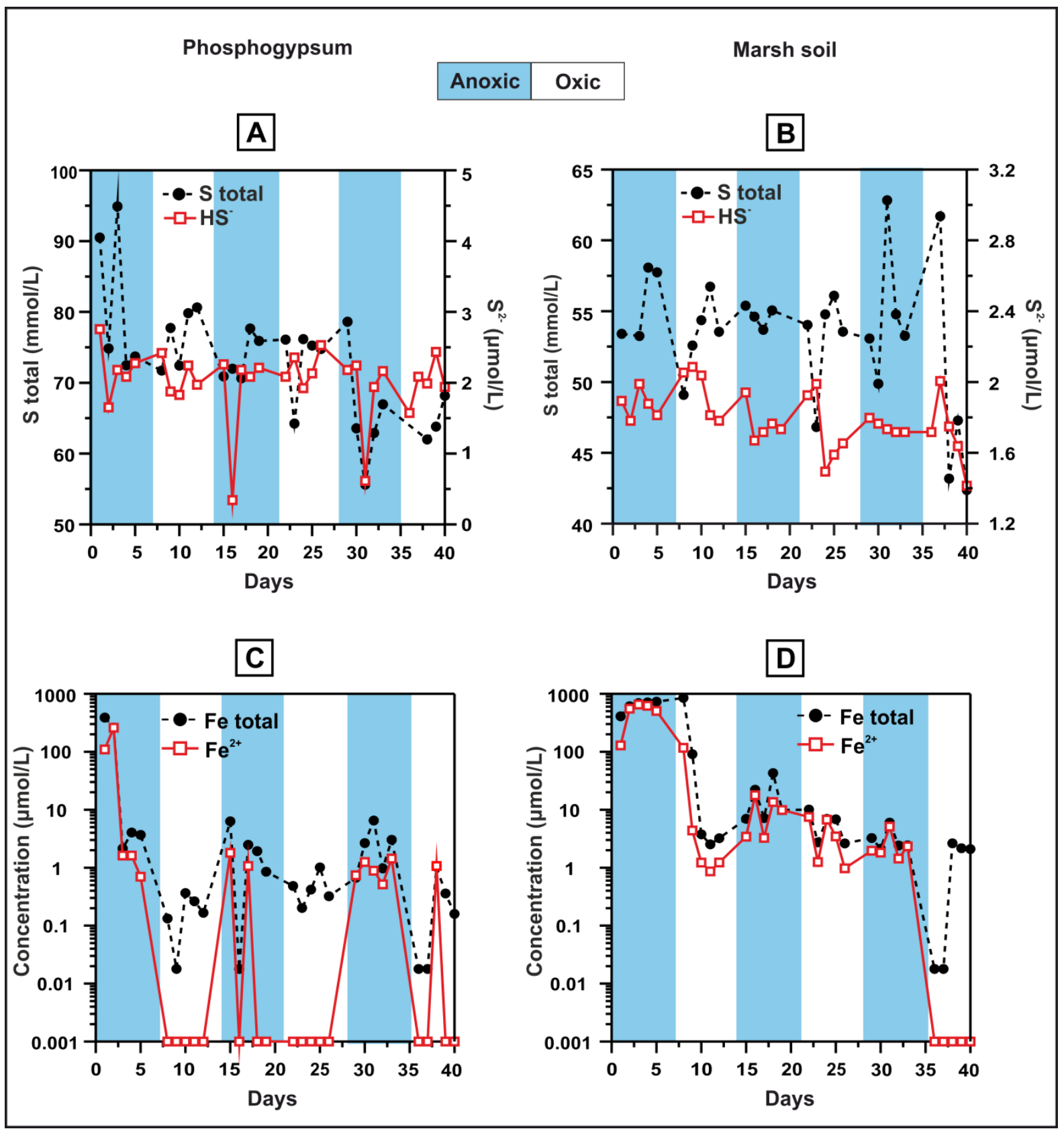

Figure 4: Concentrations of total S and $\mathrm{HS}^{-}(\mathbf{A}$ and $\mathbf{B})$, and concentrations in log scale of total $\mathrm{Fe}$, and $\mathrm{Fe}^{2+}(\mathbf{C}$ and $\mathbf{D})$, in the phosphogypsum and the marsh soil systems, respectively.

\subsection{Mobility of trace elements}

The mobility of trace elements ( $\mathrm{Zn}, \mathrm{As}, \mathrm{Cd}$ and $\mathrm{U})$ during redox oscillations was slightly different between the phosphogypsum and the marsh soil experiments, while they displayed similar behaviour in each suspension separately. The range of 
elemental concentrations was small indicating mostly a conservative behaviour during the experiments with no consistent alternations between oxic and anoxic conditions; e.g., As fluctuated only between approx. 0.03 to 0.07 and 0.08 to 0.11 $\mathrm{mmol} / \mathrm{L}$, in the phosphogypsum and the marsh soil, respectively (Table 4). The higher contaminant mobility in the marsh soil system is consistent with the lower $\mathrm{pH}$ values. An important exception to that range in phosphogypsum was an occasional abrupt rise at the last anoxic half-cycle (at the $31^{\text {st }}$ day) at all the analysed trace elements (Fig. 5A and C). On the other hand, their concentrations decreased approx. 30\% in the marsh soil on the same day (Fig. 5B and D). Concerning As speciation, the results indicated that most of the total amount was present as $\mathrm{As}^{5+}$, while $\mathrm{As}^{3+}$ was present at minimal concentrations (Fig. 5A and B). 


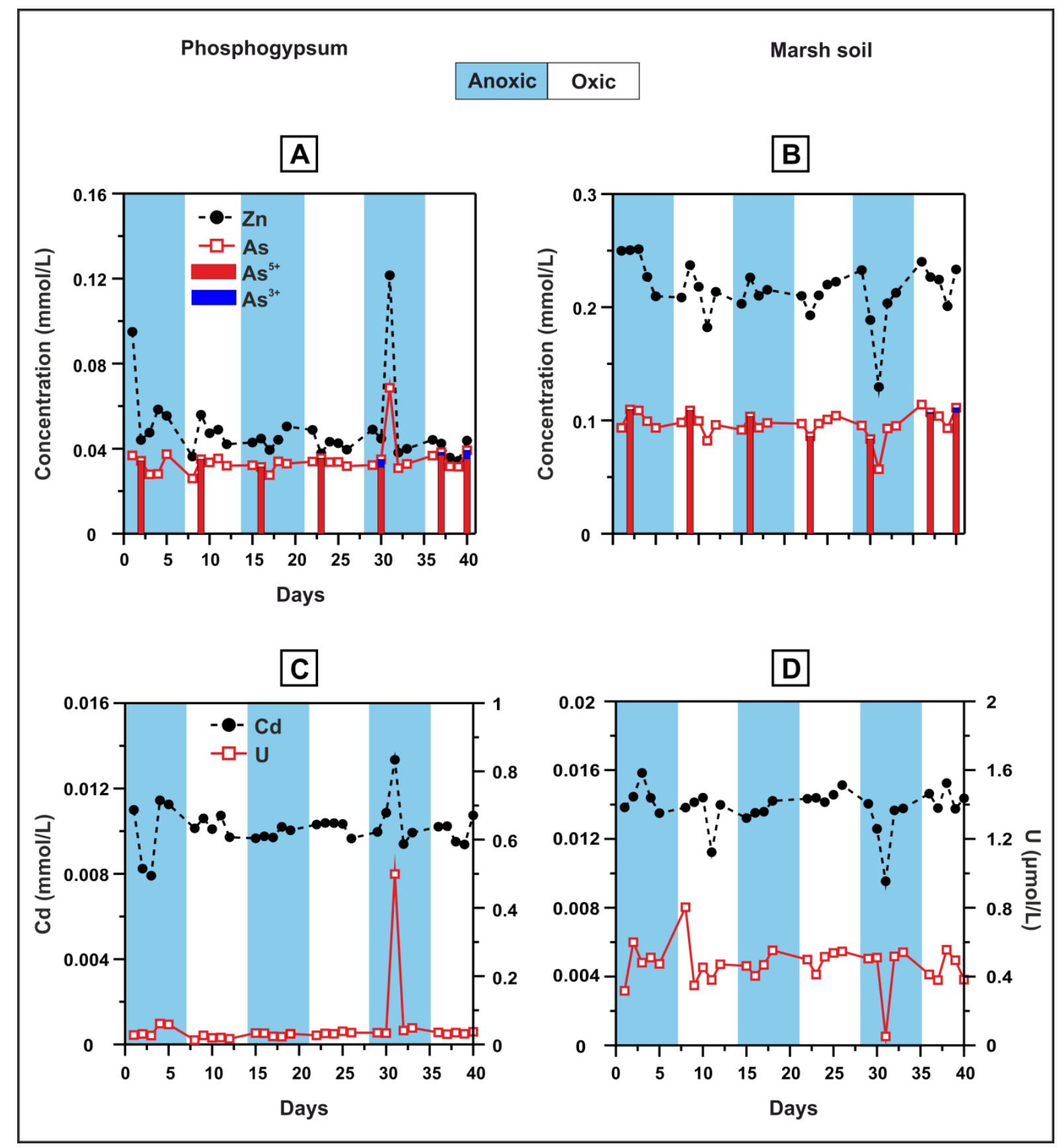

Figure 5: Concentrations of trace elements during the redox experiments in the phosphogypsum ( $\mathbf{A}$ and $\mathbf{C}$ ), and in the marsh soil (B and $\mathbf{D}$ ). Arsenic speciation is also presented for representative samples in each half-cycle (A and $\mathbf{B})$. 


\subsection{Solid phase characterisation}

The chemical analyses of the aqueous phases of both phosphogypsum and marsh soil systems after 3 redox oscillation cycles showed that $\mathrm{Fe}$ is largely removed from the solution, due to various precipitation processes. SEM-EDS analyses revealed the dominant presence of Fe solid phases at precipitates. On the one hand, in both systems, Fe phosphate is the most commonly identified Fe solid phase, and is detected independently of the redox conditions (Fig. 6A and B). Chromium was found to be adsorbed to them to some extent. On the other hand, $\mathrm{Fe}$ oxyhydroxides were not detected until completion of the second full cycle, and these carried $\mathrm{Cr}$, $\mathrm{Cu}$ and $\mathrm{Zn}$ as species in oxic, and to a lesser extent, in anoxic conditions (Fig. 6C and D). Iron was also detected in the spectra corresponding to major phases already present in the original phosphogypsum and soil materials, including gypsum, barite or fluoride.

The identification of metal sulphides was challenging in both matrices, probably, due to their low quantities that were difficult to be identified by SEM-EDS analysis. Nevertheless, some metal sulphide phases (e.g., $\mathrm{FeS}_{2}$ and $(\mathrm{Cu},-\mathrm{Fe}) \mathrm{S}_{2}$ ) were detected in the solid samples of both experiments (Fig. 6E and F), in agreement with the phases predicted to precipitate according to PHREEQC calculations (Table 3). 


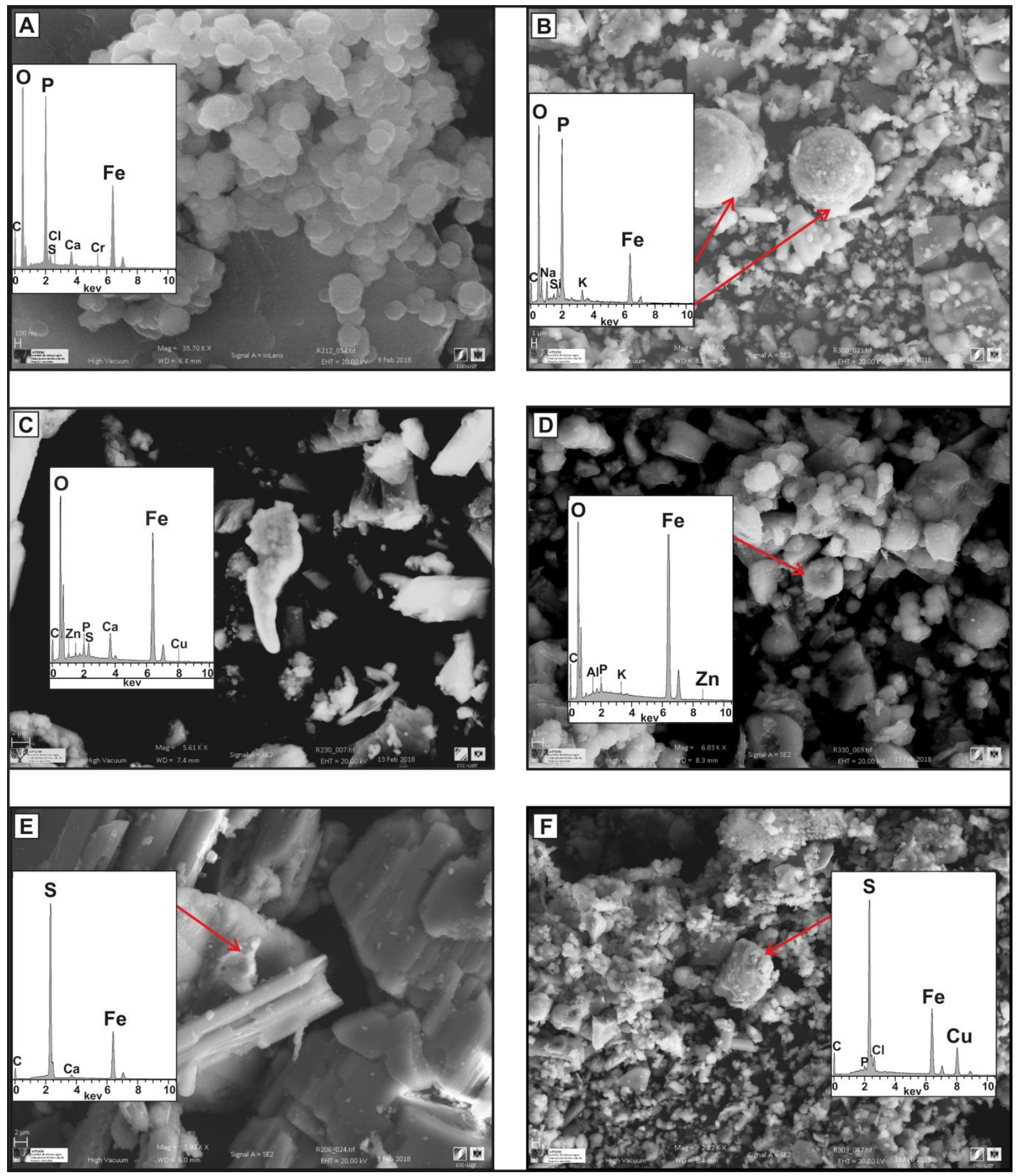

Figure 6: Solid phases identified by SEM-EDS analysis in the precipitates collected during the experiments. A and B: Fe phosphate in the second anoxic cycle of the phosphogypsum and the marsh soil systems, respectively; C and D: Iron oxyhydroxide as a sink for $\mathrm{Cu}$ and $\mathrm{Zn}$ in the last oxic cycle of the phosphogypsum and the marsh soil systems, respectively; $\mathbf{E}$ and $\mathbf{F}$ : Fe sulphide (i.e. pyrite) in the second anoxic cycle of the phosphogypsum and the marsh soil systems, respectively; Cu substitution in Fe sulphide (in F). 


\section{Discussion}

\subsection{Fe and S redox processes' effect on metal behaviour}

Sulphur and, to a lesser extent, iron are the predominant redox-sensitive elements in the phosphogypsum and the main impurities and therefore, geochemical processes occurring during redox oscillations will affect their species concentration (Pérez-López et al., 2011). In our experiments, soon after organic matter addition in each anoxic half-cycle, aqueous Fe concentration first increased, as observed in other studies (e.g., Parsons et al., 2013). However, the limited amount of $\mathrm{Fe}$ released in solution might be attributed to the little total Fe present in the solid phases and to the slow dissolution kinetics of iron oxyhydroxides. The fast drop of $\mathrm{Fe}^{+2}$ that follows indicates the precipitation of Fe phosphates (Kocar et al., 2009; Weigand et al., 2010), with phosphate ion being predominant in such phosphogypsum, and the fast sorption on remaining Fe oxides or occasional fast FeS precipitation (Wolthers at al., 2005). After this dramatic drop in the phosphogypsum first anoxic half-cycle and the marsh soil first oxic half-cycle, the initial amount of total Fe was never recovered and remained continuously low. The reduction of $\mathrm{Fe}$ oxyhydroxides, e.g., in the initial reducing period on the phosphogypsum, is catalysed by microorganisms and does not occur in the subsequent reducing period. Nevertheless, this could be attributed to the time needed for the development of anaerobic microbial activity (Rinklebe and Langer, 2008; Langer and Rinklebe, 2009), which could be longer compared to our short one week anoxic periods (Frohn et al., 2014), or to the acidic conditions that hindered the establishment of the anoxic environment (Phan et al., 2018). These conditions may arise from the nil formation of Fe oxyhydroxides during oxic periods due to the main precipitation of phosphate. 
In the phosphogypsum experiment, $\mathrm{Fe}^{2+}$ in solution first decreases in the oxic half cycles as Eh increases, and free $\mathrm{Fe}^{2+}$ oxidatively precipitates as $\mathrm{FeOOH}$, a phenomenon catalysed by adsorption of $\mathrm{Fe}^{2+}$ on mineral surfaces (Silvester et al., 2005), or as amorphous $\mathrm{Fe}^{3+}$ phosphates. The oxidation of $\mathrm{Fe}^{2+}$ originating from pyrite oxidation and $\mathrm{Fe}$-(oxyhydr)oxides to $\mathrm{Fe}^{3+}$ phases was, also, described in similar studies (e.g., Phan et al., 2019). The rapid precipitation of poorly crystalline $\mathrm{Fe}^{3+}$ minerals under oxic conditions has been described by Megonigal et al. (2003). In turn, these precipitated Fe phases re-dissolved in the subsequent anoxic cycle releasing $\mathrm{Fe}$, which was again reduced to $\mathrm{Fe}^{2+}$, as previously reported (AntićMladenović et al., 2011; Frohne et al., 2011; 2014), which implies the formation of high surface/volume ratio particles, i.e. $\mathrm{Fe}^{2+}$ nanoparticles. The precipitation of $\mathrm{Fe}^{+3}$ bearing solid phases following $\mathrm{Fe}^{2+}$ oxidation in the studied systems is one of the driving processes of "The Iron Wheel" geochemical cycling, which is used to describe the alternating reductive dissolution and oxidation-precipitation processes of iron. This cycling can interact with $\mathrm{P}$ leading to the abundant formation of $\mathrm{Fe}$ phosphates (i.e., vivianite and strengite), as already described in a similar redox sensitive system by Busigny et al. (2016). This process is consistent with the low sulphide concentrations in our systems that allows the dissolved Fe to accumulate (Davison, 1993; Busigny et al., 2016).

In contrast, during the marsh soil experiment, oxidation of $\mathrm{Fe}^{2+}$ and consequently, Fe precipitation were less important, indicating its resistance to oxidation (i) by low $\mathrm{pH}$, and (ii) possibly by competence with Dissolved Organic Matter (DOM); the $\mathrm{Fe}^{2+}$ oxygenation kinetics are highly $\mathrm{pH}$ dependent, and thus, faster at $\mathrm{pH} 4.5$ than at $\mathrm{pH} 3.5$. Nevertheless, the differences between $\mathrm{Fe}^{2+}$ and $\mathrm{Fe}-$ 
total were slightly higher in oxic cycles implying the presence of e.g., $\mathrm{Fe}^{3+}$ organic complexes in the solution.

The conservative behaviour of the metals in the present experiments indicated their poor adsorption to Fe minerals and their poor co-precipitation, i.e., in the case of As due to $\mathrm{SO}_{4}{ }^{2-}$ competition, while $\mathrm{Fe}^{2+}$ surface is oxidised, a case in agreement with other studies (Frohne et al., 2011; 2014). Low pH conditions could have prevented those processes, as the adsorption capacity of trace elements to Fe minerals is low in acidic environments (Schulz-Zunkel and Krüger, 2009), given that both the surface of those minerals and the metals of interest $(\mathrm{Zn}, \mathrm{Cd}$ and $U)$ are positively charged. Thus, the results revealed higher soluble concentrations than expected and a general conservative behaviour, especially for $\mathrm{Zn}$, As and $\mathrm{Cd}$ concentrations in solution. High mobilization of metals during acidic conditions was also detected in other studies on redox dynamics (e.g., Chuan et al., 1996; Wiegand et al., 2009; Miller et al., 2010). Organic matter is another important parameter that controls the fate of metals in redox dynamics, as reported by Grybos et al. (2007), due to its high affinity to complex and adsorb metal cations ( $\mathrm{Cd}, \mathrm{Cu}, \mathrm{Ni}$ and $\mathrm{Zn}$ ) on negatively surface charged carboxyl groups (Laveuf and Cormu, 2009; Frohne et al., 2011). Another possible explanation is the synergic effect of the presence of various contaminants included in the same suspension at the beginning of the experiment, which could affect each other's behaviour and compete for ion complexation (Couture et al., 2015). The exceptional decrease of the available trace elements during the marsh soil experiment (i.e. at the $31^{\text {st }}$ day at the last anoxic cycle; Fig. 5B and D) could indicate their occasional co-precipitation to the available Fe minerals.

In anoxic and acidic environments (around $\mathrm{pH} 4$ ), the sulphur produced during the oxidation of organic matter is expected to react with the dissolved $\mathrm{Fe}^{2+}$, which is 
produced from the bacteria-catalysed reduction of $\mathrm{Fe}^{3+}$ oxyhydroxides, to form monosulphides of insoluble Fe (Berner, 1970). The overall reaction would be (Eq. 1):

$$
4 \mathrm{FeOOH}_{(\mathrm{s})}+4 \mathrm{SO}_{4}{ }^{2-}+9 \mathrm{CH}_{2} \mathrm{O}+8 \mathrm{H}^{+} \rightarrow 4 \mathrm{FeS}_{(\mathrm{s})}+9 \mathrm{CO}_{2}+15 \mathrm{H}_{2} \mathrm{O}(1)
$$

Therefore, the available Fe and the remaining metal ions released during the anoxic half cycles could precipitate as metal sulphides. However, this process did not seem to be important in the current experiments, as indicated by the minimal decrease of sulphide concentration (Fig. 4A) and the poor metal sulphide identification during mineralogical analysis. The limited present activity of SRB could be responsible for this effect, and the established acidic conditions might have inhibited their development (Blodau, 2006; Karimian et al., 2018) and subsequently, prevented the microbial sulphate reduction (Phan et al., 2018). The low pH conditions might have prevented the preservation of the potential sulphide precipitates, and thus, being also responsible for their poor identification, as they are reported to be rather soluble under acidic conditions (Liu et al., 2009; Frohne et al., 2011). Given the more acidic conditions prevailing in the marsh soil system, sulphate reduction and sulphide precipitation was nil. Hence, in both systems, sulphide concentrations were too low to favour metal sulphide precipitation. More importantly the dominant Fe phosphate precipitation should have prevented the formation of sulphides, being the main precipitation process that controlled the mobility of $\mathrm{Fe}^{2+}$. Therefore, the conventional driving process of sulphide precipitation expected in estuarine salt marsh systems is not favoured when the source of the contaminants is a waste rich in phosphates, as occurs in the studied area. 
In addition, the available metal ions appeared in higher concentrations than the aqueous sulphide ions and especially, on the $31^{\text {st }}$ day of the phosphogypsum experiment the former increased, while the latter decreased (Fig. 4A; Fig 5A and C). This could be explained by the dissolution of some solid phases on which the metals were adsorbed (e.g., Fe oxyhydroxides) and their subsequent release. This would imply the coupled reaction (1) of reductive dissolution of Fe oxyhydroxides and sulphate reduction with precipitation of metal sulphides. However, since there is no evident decrease of trace metals during oxic cycles despite Fe oscillation, the $\mathrm{Fe}$ oxyhydroxides that dissolved could be also contained in the initial phosphogypsum, concomitant with the identified phases by SEM-EDS analysis. With respect to the marsh soil experiment, the abnormal behaviour of sulphide with respect to the marsh soil -low peaks (although not significant) during the last two oxic half cycles (Fig. 4B)- could be explained by the decomposition of the present organic matter that favoured the development of anoxic microenvironments.

\subsection{As and U behaviour}

Given that As was detected mostly as $\mathrm{As}^{5+}$ under both oxic and anoxic conditions, no correlation was identified between As species and redox conditions. Arsenate, on the contrary to $\mathrm{As}^{3+}$, is chemically similar to phosphate, so they compete for the same cations or binding sites in soils (Manning and Goldberg, 1996; Signes-Pastor et al., 2007). Huge aqueous phosphate concentrations present in both phosphogypsum and marsh soil suspensions could be responsible for As high mobility, as $\mathrm{As}^{5+}$ was the predominant species during the experiment. Phosphate is competing effectively with As in terms of sorption processes on iron minerals and has a strong affinity to sorb onto iron oxide minerals (Manning and Goldberg, 1996; Gao and Mucci, 2001; Dixit and Hering, 2003), hence preventing the decrease of As 
mobility during the presented experiments, among other reasons. In addition, the fact that $\mathrm{As}^{5+}$ was not reduced to $\mathrm{As}^{3+}$ during the anoxic conditions did not favour the formation of arsenic sulphide minerals, as only arsenite among arsenic ions has a strong affinity for S (Signes-Pastor et al., 2007). This enhances the conservative behaviour of As. Some exceptions to the mobility of As, e.g., day 31 at the marsh soil, could be attributed to $\mathrm{As}^{5+}$ sorption onto $\mathrm{Fe}^{3+}$ phosphate minerals, as has been reported by Lenoble et al. (2005).

With respect to $U$, it presented a less conservative behaviour during redox cycling than the rest of the contaminants, as it displayed often fluctuations even during the same half cycle. Uranium is most likely present as $U^{6+}$ in oxic conditions, while it could be reduced to the less soluble form of $\mathrm{U}^{4+}$ in anoxic conditions and thus, be immobilised by precipitation of $\mathrm{UO}_{2(\mathrm{~s})}$ or monomeric $\mathrm{U}^{+5}$. This process could occur through several reduction pathways in organic-rich zones, including the materials of the presented experiments that are organic matter rich, such as abiotic reduction by iron sulphides that produces uraninite or as biological mediation via enzymatic activity (Hyun et al., 2012). This was more evident in the marsh soil experiment and especially, at the last two anoxic half cycles, being in agreement with the elevated values of organic matter (Figs. 3D and 4D).

\section{Conclusions}

Phosphogypsum disposal areas, such as the Huelva phosphogypsum pile disposed directly on the salt marshes of the Tinto River-, are sensitive to redox conditions. These conditions control the behaviour of dominant redox sensitive species in phosphogypsum, i.e., $\mathrm{Fe}$ and $\mathrm{S}$, and subsequently, the related geochemical processes and the mobility of the potentially toxic trace elements that discharge from the waste. Our results reveal a rapid and significant decrease of 
aqueous Fe upon the start of anoxic conditions in the phosphogypsum experiment and upon the start of the oxic period in the marsh soil experiment, coherent with a fast precipitation of Fe phosphate. Iron decrease from solution was also consistent, to a lower extent, with precipitation of $\mathrm{Fe}(\mathrm{III})$ oxyhydroxides. In contrast, sulphate reduction and FeS precipitation, usually very active in estuarine salt marsh systems, were not favoured in the current study, consistent with the absence of SRB. In addition, the insufficient amount of sulphide available compared to trace elements concentrations hinders Fe, Cd or Zn sulphide precipitation processes. Therefore, the formation of metal sulphides appeared to be secondary compared to the precipitation of Fe phosphates, which in turn controls the mobility of the metal ions independently of the redox conditions. Immobilisation of the contaminants of interest $(\mathrm{Zn}, \mathrm{As}, \mathrm{Cd}$, U) was not favoured during the current experiments, possibly due to prevailing acidic conditions, elevated concentrations of organic matter, and the synergetic effect of various contaminants competing for the same precipitated phases. In general, the studied trace elements are more mobile in the salt marsh soil than in the phosphogypsum stack, due to repetitively lower $\mathrm{pH}$ and higher Eh values.

Although SRB activity can be favoured by a cover rich in organic matter and abundant of sulphate -as already implemented in parts of the waste- this study shows that this process cannot provide a substantial improvement in the quality of the leachates, given that contaminants mobility is not affected importantly by redox oscillations. Based on the experiments, natural attenuation does not seem to work in this industrial ecosystem, and different remediation actions are necessary. However, the relatively short period of each half-cycle may not represent well the field conditions as one week half-cycles won't provide enough time and the ideal 
conditions for the development of microbial activity and thus, to lead to metal precipitation processes.

\section{Acknowledgements}

This work was supported by the Regional Government of Andalusia through the "Junta de Andalucía" research projects P12-RNM-2260 and RNM-131 and by the Spanish Ministry of Economic and Competitiveness through the research project CAPOTE (CGL2017-86050-R). The authors are very grateful to the funding support for the Committee of Experts on "The environmental diagnosis and the proposal of measures of restoration of the phosphogypsum stacks of Huelva", appointed by the City Hall of Huelva. Dr. E. M. is grateful to the funding support of International Mobility launched by the University of Granada and CEI-BIOTIC Granada 2015/2016. Dr. A. Parviainen acknowledges the 'Juan de la Cierva - Incorporación' (IJCl-2016-27412) Fellowship and Dr. C. Marchesi the "Ramón y Cajal" (RYC-201211314) Fellowship financed by the Spanish Ministry of Economy and Competitiveness (MINECO).

We are immensely grateful to Dr. C.R. Cánovas and Dr. F. Macías for their help during the sampling. We also thank Dr. Delphine Tisserand and Dr. Sarah Bureau for their assistance during laboratory and analytical work. Redox oxcillation experiments were performed within the analytical chemistryl platform of ISTerre (OSUG France). We acknowledge the University of Huelva (Spain) and the Andalusian Institute of Earth Sciences (IACT) in Granada (Spain) for the solution elemental analyses, the University of Montpellier (France) (AETE-ISO platform, OSU-OREME/Université de Montpellier) for the aqueous As speciation, the Institute of Geosciences of the Environment (IGE) and the Institute of Earth Sciences 
(ISTerre) in Grenoble (France) for the ATP measurements, and for DOC, S and Fe analyses, respectively. Solid phase characterisation took place at the Instrumentation Centre (CIC) of the University of Granada, Spain.

\section{References}

Allison, J.D., Brown, D.S., Novo-Gradac, K.J., 1991. MINTEQA2/PRODEFA2, A Geochemical Assessment Model for Environmental Systems. Version 3. 0 User's Manual, Environmental Research Laboratory, Office of Research and Development, US Environmental Protection Agency, EPA/600/3-911021, Athens, GA.

Ann, Y., Reddy, K. R., \& Delfino, J. J., 2000. Influence of redox potential on phosphorus solubility in chemically amended wetland organic soils. Ecological Engineering, 14(12), 169-180.

Andrade, M. L., Reyzabal, M. L., Marcet, P., \& Montero, M. J., 2002. Industrial impact on marsh soils at the Bahia Blanca Ria, Argentina. Journal of Environmental Quality, 31(2), 532-538.

Andrade, M. L., Covelo, E. F., Vega, F. A., \& Marcet, P., 2004. Effect of the Prestige oil spill on salt marsh soils on the coast of Galicia (northwestern Spain). Journal of Environmental Quality, 33(6), 2103-2110.

Antić-Mladenović, S., Rinklebe, J., Frohne, T., Stärk, H. J., Wennrich, R., Tomić, Z., \& Ličina, V., 2011. Impact of controlled redox conditions on nickel in a serpentine soil. Journal of Soils and Sediments, 11(3), 406-415.

Busigny, V., Jézéquel, D., Cosmidis, J., Viollier, E., Benzerara, K., Planavsky, N. J., ... \& Michard, G., 2016. The Iron Wheel in Lac Pavin: Interaction with Phosphorus Cycle. In Lake Pavin, 205-220. Springer, Cham.

Berner, R. A., 1970. Sedimentary pyrite formation. American journal of science, 268(1), 1-23.

Blodau, C., 2006. A review of acidity generation and consumption in acidic coal mine lakes and their watersheds. Science of the Total Environment, 369 (1e3), 307e332.

Bohari, Y., Astruc, A., Astruc, M., Cloud, J., \& Angot, A. P., 2001. Improvements of hydride generation for the speciation of arsenic in natural freshwater samples by HPLC-HGAFS. Analytical Atomic Spectrometry, 16, 774-778.

Borch, T., Kretzschmar, R., Kappler, A., Cappellen, P.V., Ginder-Vogel, M., Voegelin, A. and Campbell, K., 2009. Biogeochemical redox processes and their impact on contaminant dynamics. Environmental Science \& Technology, 44(1), pp.15-23. 
Borrego, J. F., Carro, B. M., Gil, J. A. G., De la Torre, M. L., Valente, T., \& Santisteban, M., 2013. Control factors on the composition of superficial sediments in estuaries of the coast of Huelva (SW Spain): a statistical approach. Cuadernos de Geología Ibérica= Journal of Iberian Geology: an international publication of earth sciences, (39), 223232.

Cánovas, C. R., Macías, F., Pérez-López, R., Basallote, M. D., \& Millán-Becerro, R., 2018. Valorization of wastes from the fertilizer industry: current status and future trends. Journal of cleaner production, 174, 678-690.

Castillo, J., Pérez-López, R., Sarmiento, A.M. and Nieto, J.M., 2012. Evaluation of organic substrates to enhance the sulfate-reducing activity in phosphogypsum. Science of the Total Environment, 439,106-113.

Chuan, M. C., Shu, G. Y., \& Liu, J. C., 1996. Solubility of heavy metals in a contaminated soil: effects of redox potential and pH. Water, Air, and Soil Pollution, 90(3-4), 543556.

Church, C. D., Wilkin, R. T., Alpers, C. N., Rye, R. O., \& McCleskey, R. B., 2007. Microbial sulfate reduction and metal attenuation in $\mathrm{pH} 4$ acid mine water. Geochemical Transactions, 8(1), 10.

Cline, J. D. (1969). Spectrophotometric determination of hydrogen sulfide in natural waters. Limnology and Oceanography, 14(3), 454-458.

Couture, R.M., Charlet, L., Markelova, E., Madé, B. and Parsons, C.T., 2015. On-off mobilization of contaminants in soils during redox oscillations. Environmental science \& technology, 49(5), pp.3015-3023.

Davison, W., 1993. Iron and manganese in lakes. Earth-Science Reviews, 34(2), 119-163.

Dixit, S., \& Hering, J. G., 2003. Comparison of arsenic (V) and arsenic (III) sorption onto iron oxide minerals: implications for arsenic mobility. Environmental science \& technology, 37(18), 4182-4189.

Du Laing, G., Rinklebe, J., Vandecasteele, B., Tack, F.M.G., 2009. Trace metal behaviour in estuarine and riverine floodplain soils and sediments: a review. Science of the Total Environment, 407, 3972-3985.

Hammes, F., Goldschmidt, F., Vital, M., Wang, Y., \& Egli, T., 2010. Measurement and interpretation of microbial adenosine tri-phosphate (ATP) in aquatic environments. Water Research, 44(13), 3915-3923.

Husson, O. (2013). Redox potential (Eh) and $\mathrm{pH}$ as drivers of soil/plant/microorganism systems: a transdisciplinary overview pointing to integrative opportunities for agronomy. Plant and Soil, 362(1-2), 389-417.

Hyun, S. P., Davis, J. A., Sun, K., \& Hayes, K. F., 2012. Uranium (VI) reduction by iron (II) monosulfide mackinawite. Environmental science \& technology, 46(6), 3369-3376. 
IAEA, 2013. Radiation Protection and Management of Norm Residues in the Phosphate Industry. Safety Reports Series No. 78 d Vienna: International Atomic Energy Agency, p. 308.

Florentino, A. P., Weijma, J., Stams, A. J., \& Sánchez-Andrea, I., 2015. Sulfur reduction in acid rock drainage environments. Environmental science \& technology, 49(19), 1174611755.

Frohne, T., Rinklebe, J., Diaz-Bone, R.A. and Du Laing, G., 2011. Controlled variation of redox conditions in a floodplain soil: impact on metal mobilization and biomethylation of arsenic and antimony. Geoderma, 160(3), pp.414-424.

Frohne, T., Rinklebe, J., \& Diaz-Bone, R. A., 2014. Contamination of floodplain soils along the Wupper River, Germany, with As, $\mathrm{Co}, \mathrm{Cu}, \mathrm{Ni}, \mathrm{Sb}$, and $\mathrm{Zn}$ and the impact of predefinite redox variations on the mobility of these elements. Soil and Sediment Contamination: An International Journal, 23(7), 779-799.

Gao, Y., \& Mucci, A., 2001. Acid base reactions, phosphate and arsenate complexation, and their competitive adsorption at the surface of goethite in $0.7 \mathrm{M} \mathrm{NaCl}$ solution. Geochimica et Cosmochimica Acta, 65(14), 2361-2378.

Grybos, M., Davranche, M., Gruau, G., \& Petitjean, P., 2007. Is trace metal release in wetland soils controlled by organic matter mobility or Fe-oxyhydroxides reduction?. Journal of colloid and interface science, 314(2), 490-501.

Karimian, N., Johnston, S. G., \& Burton, E. D., 2018. Iron and sulfur cycling in acid sulfate soil wetlands under dynamic redox conditions: A review. Chemosphere, 197, 803816.

Kocar, B. D., \& Fendorf, S., 2009. Thermodynamic constraints on reductive reactions influencing the biogeochemistry of arsenic in soils and sediments. Environmental Science \& Technology, 43(13), 4871-4877.

Langer, U., \& Rinklebe, J., 2009. Lipid biomarkers for assessment of microbial communities in floodplain soils of the Elbe River (Germany). Wetlands, 29(1), 353-362.

Laveuf, C., \& Cornu, S., 2009. A review on the potentiality of rare earth elements to trace pedogenetic processes. Geoderma, 154(1-2), 1-12.

Lenoble, V., Laclautre, C., Deluchat, V., Serpaud, B., \& Bollinger, J. C.. 2005. Arsenic removal by adsorption on iron (III) phosphate. Journal of hazardous materials, 123(13), 262-268.

Liu, J., Valsaraj, K.T., DeLaune, R.D., 2009. Inhibition of mercury methylation by iron sulfides in an anoxic sediment. Environ. Eng. Sci. 26, 833-840.

Lottermoser BG., 2007. Mine wastes: characterization, treatment, environmental impacts. 2nd ed. Berlin Heidelberg: Springer-Verlag. 
Macías, F., Cánovas, C. R., Cruz-Hernández, P., Carrero, S., Asta, M. P., Nieto, J. M., \& Pérez-López, R., 2017. An anomalous metal-rich phosphogypsum: characterization and classification according to international regulations. Journal of hazardous materials, 331, 99-108.

Manning, B. A., \& Goldberg, S., 1996. Modeling competitive adsorption of arsenate with phosphate and molybdate on oxide minerals. Soil Science Society of America Journal, 60(1), 121-131.

Markelova, E., Couture, R. M., Parsons, C. T., Markelov, I., Madé, B., Van Cappellen, P., \& Charlet, L., 2018. Speciation dynamics of oxyanion contaminants (As, Sb, Cr) in argillaceous suspensions during oxic-anoxic cycles. Applied Geochemistry, 91, 7588.

Megonigal, J.P., Hines, M.E., Visscher, P.T., 2003. Anaerobic metabolism: linkages to trace gases and aerobic processes. In: Holland, H.D., Turekian, K.K. (Eds.), Treatise on Geochemistry. Pergamon, Oxford, pp. 317e424.

Miller, F. S., Kilminster, K. L., Degens, B., \& Firns, G. W., 2010. Relationship between metals leached and soil type from potential acid sulphate soils under acidic and neutral conditions in Western Australia. Water, air, and soil pollution, 205(1-4), 133.

Papanicolaou, F., Antoniou, S. and Pashalidis, I., 2010. Redox chemistry of sulphate and uranium in a phosphogypsum tailings dump. Journal of environmental radioactivity, 101(8), pp.601-605.

Papaslioti, E. M., Pérez-López, R., Parviainen, A., Macías, F., Delgado-Huertas, A., Garrido, C. J., Marhesi, C. \& Nieto, J. M., 2018. Stable isotope insights into the weathering processes of a phosphogypsum disposal area. Water research, 140, 344-353.

Parkhurst, D.L., \& Appelo, C.A.J., 2005. PHREEQC-2 version 2.12: A hydrochemical transport model. US Geological Survey Central Region Research, USGS Water Resources Division, http://wwwbrr. cr. usgs. gov/projects/GWC_coupled/phreeqc.

Parsons, C. T., Couture, R. M., Omoregie, E. O., Bardelli, F., Greneche, J. M., Roman-Ross, G., \& Charlet, L., 2013. The impact of oscillating redox conditions: Arsenic immobilisation in contaminated calcareous floodplain soils. Environmental pollution, 178, 254-263.

Pérez-López, R., Castillo, J., Sarmiento, A.M. and Nieto, J.M., 2011. Assessment of phosphogypsum impact on the salt-marshes of the Tinto river (SW Spain): Role of natural attenuation processes. Marine pollution bulletin, 62(12), pp.2787-2796.

Pérez-López, R., Macías, F., Cánovas, C.R., Sarmiento, A.M., Pérez-Moreno, S.M., 2016. Pollutant flows from a phosphogypsum disposal area to an estuarine environment: An insight from geochemical signatures. Science of the Total Environment, 553, $42-$ 51. 
Pérez-López, R., Carrero S., Cruz-Hernández, P., Asta, M.P., Macías, F., Cánovas, C.R., Guglieri, C., Nieto, J.M., 2018. Sulfate reduction processes in salt marshes affected by phosphogypsum: geochemical influences on contaminant mobility. Journal of Hazardous Materials, 350, 154-161.

Phan, V. T., Bardelli, F., Le Pape, P., Couture, R. M., Fernandez-Martinez, A., Tisserand, D., Bernier-Latmani, R. \& Charlet, L., 2018. Interplay of $S$ and As in Mekong Delta sediments during redox oscillations. Geoscience Frontiers.

Phan, V. T., Bernier-Latmani, R., Tisserand, D., Bardelli, F., Le Pape, P., Frutschi, M., Gehin, A., Couture, R. M. \& Charlet, L., 2019. As release under the microbial sulfate reduction during redox oscillations in the upper Mekong delta aquifers, Vietnam: a mechanistic study. Science of The Total Environment.

Polizzotto, M.L., Kocar, B.D., Benner, S.G., Sampson, M. and Fendorf, S., 2008. Nearsurface wetland sediments as a source of arsenic release to ground water in Asia. Nature, 454(7203), pp.505-508.

Rinklebe, J., \& Langer, U. (2008). Floodplain soils at the Elbe River, Germany, and their diverse microbial biomass. Archives of Agronomy and Soil Science, 54(3), 259-273.

Schulz-Zunkel, C., \& Krueger, F., 2009. Trace metal dynamics in floodplain soils of the River Elbe: a review. Journal of environmental quality, 38(4), 1349-1362.

Signes-Pastor, A., Burló, F., Mitra, K., \& Carbonell-Barrachina, A. A., 2007. Arsenic biogeochemistry as affected by phosphorus fertilizer addition, redox potential and $\mathrm{pH}$ in a west Bengal (India) soil. Geoderma, 137(3-4), 504-510.

Silvester, E., Charlet, L., Tournassat, C., Gehin, A., Grenèche, J. M., \& Liger, E., 2005. Redox potential measurements and Mössbauer spectrometry of Fell adsorbed onto Felll (oxyhydr) oxides. Geochimica et Cosmochimica Acta, 69(20), 4801-4815.

Thompson, A., Chadwick, O.A., Rancourt, D.G., Chorover, J., 2006. Iron-oxide crystallinity increases during soil redox oscillations. Geochim. Cosmochim. Acta 70, 1710-1727. doi:10.1016/j.gca.2005.12.005

Vega, F. A., Covelo, E. F., \& Andrade, M. L., 2008. Impact of industrial and urban waste on the heavy metal content of salt marsh soils in the southwest of the province of Pontevedra (Galicia, Spain). Journal of Geochemical Exploration, 96(2-3), 148-160.

Vega, F. A., Covelo, E. F., Cerqueira, B., \& Andrade, M. L., 2009. Enrichment of marsh soils with heavy metals by effect of anthropic pollution. Journal of hazardous materials, 170(2-3), 1056-1063.

Viollier, E., Inglett, P. W., Hunter, K., Roychoudhury, A. N., \& Van Cappellen, P. , 2000. The ferrozine method revisited: Fe (II)/Fe (III) determination in natural waters. Applied geochemistry, 15(6), 785-790. 
Wang, Y., Tang, C., Wu, J., Liu, X., \& Xu, J., 2013. Impact of organic matter addition on pH change of paddy soils. Journal of soils and sediments, 13(1), 12-23.

Watts, M.P. and Lloyd, J.R., 2013. Bioremediation via microbial metal reduction. In Microbial Metal Respiration (pp. 161-201). Springer Berlin Heidelberg.

Weigand, H., Mansfeldt, T., Bäumler, R., Schneckenburger, D., Wessel-Bothe, S., \& Marb, C. (2010). Arsenic release and speciation in a degraded fen as affected by soil redox potential at varied moisture regime. Geoderma, 159(3-4), 371-378.

Wiegand, J., Aschan, G., Kraus, U., Piontek, J., \& Mederer, J., 2009. Chemical fractionation and soil-to-plant transfer characteristics of heavy metals in a sludge deposit field of the river Ruhr, Germany. Soil \& Sediment Contamination, 18(1), 14-29.

Wu, W.M., Carley, J., Gentry, T., Ginder-Vogel, M.A., Fienen, M., Mehlhorn, T., Yan, H., Caroll, S., Pace, M.N., Nyman, J., Luo, J., Gentile, M.E., Fields, M.W., Hickey, R.F., Gu, B., Watson, D., Cirpka, O.A., Zhou, J., Fendorf, S., Kitanidis, P.K., Jardine, P.M., Criddle, C.S., 2006. Pilot-scale in situ bioremedation of uranium in a highly contaminated aquifer. 2. Reduction of $\mathrm{U}(\mathrm{VI})$ andgeochemical control of $\mathrm{U}(\mathrm{VI})$ bioavailability. Environ. Sci. Technol. 40, 3986-3995.

Yang, J., Liu, W., Zhang, L., \& Xiao, B., 2009. Preparation of load-bearing building materials from autoclaved phosphogypsum. Construction and Building Materials, 23(2), 687693.

Yu, K., Böhme, F., Rinklebe, J., Neue, H.-U., DeLaune, R.D., 2007. Major biogeochemical processes in soils - a microcosm incubation from reducing to oxidizing conditions. Soil Sci. Soc. Am. J. 71, 1406-1417. 